\title{
Staining method for the examination of the small intestinal villous pattern in necropsy material
}

SYNOPSIS A new technique for the rapid identification of villous structure in postmortem materia括 is described. It has been used with success for over a year and has proved superior in the authorg hands to previously described methods.

Morphological and histological examination of intestinal mucosal biopsy material obtained by peroral instrumentation has made an outstanding contribution to the study and understanding of small intestinal disease. Postmortem examination of small intestinal mucosa has been unsatisfactory and disappointing, the histological sections showing in most instances such extensive autolytic changes that accurate assessment of villous structure is impossible. Portmortem autolysis of alimentary mucosa is rapid since it is so rich in proteolytic enzymes (Abraham, 1962).

Recent awareness of intestinal mucosal abnormalities in conditions other than the coeliac syndrome, for example, carcinoma (Hindle and Creamer, 1965; Dymock, 1966), ulcerative colitis (Salem, Truelove, and Richards, 1964), and skin disease (Shuster and Marks, 1965) has further necessitated the development of a method for the identification of villous structure in necropsy material. Creamer and Leppard (1965) have described a method for the preparation of specimens and their examination under the dissecting microscope. In this communication we describe a further development of this technique using haematoxylin staining which facilitates the rapid identification of villous structure. Further, this has proved suitable for study by a monocular microscope and for photographic recording.

\section{MATERIALS AND METHODS}

MATERIALS Specimens of small intestinal tissue were obtained at routine necropsy on patients dying in a large general hospital.

Received for publication 26 March 1968.
Formol calcium was made up as follows:

$$
\begin{aligned}
& \begin{array}{l}
\text { Calcium acetate } \ldots \ldots \ldots \ldots \ldots \ldots \\
\text { Formaldehyde......... } 2 \text { g }
\end{array} \\
& \text { Water......... to } \ldots \ldots \ldots \ldots \text {. } 100 \mathrm{ml}
\end{aligned}
$$

Haematoxylin solution Mayer's haemalum was use Of the concentrated haematoxylin 20 to 40 drops wers added to $50 \mathrm{ml}$ of water before use.

Small intestinal samples, preferabiy from duodenunग proximal jejunum, and ileum were obtained at necrops The bowel was opened longitudinally and cleared of debris by gentle lavage with formol saline. A rectangula section of full-thickness tissue approximately $3 \times 3 \mathrm{~cm}$ was laid out on a piece of thin card and fixed in $10 \%$ formol calcium. After a minimum period of 24 hours in fixative, a $2 \mathrm{~cm}$ square block, chosen to include bot mucosal folds and intervening troughs, was cut out and pinned to a firm piece of card. The specimen was the placed in the haematoxylin solution overnight. Thereafter the specimen was dehydrated in increasing concentration of alcohol and cleared in xylene. The block of tissue was then detached from the card and immersed in xylene iQ an embryo staining dish or Petri dish, and examine under the light microscope, using a $\times \mathbf{4}$ scanning objecos tive. While a slightly better view may be obtained with dissecting microscope, this is not essential.

\section{RESULTS}

This method has now been in routine use for over year and has proved adequate at all times. The specimens have included all types of mucosa from the normal finger villi to broad leaves, convoluted ridges, mosaics, and flat patterns. All have bee examined satisfactorily. In many instances tissue taken at the same time for histological examination proved valueless. 


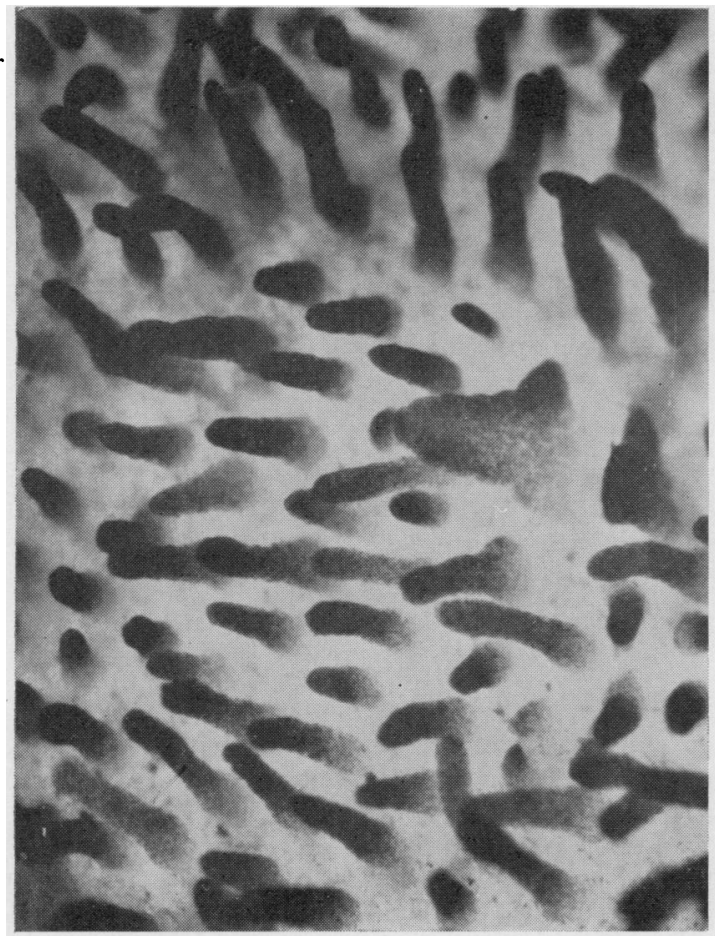

FIG. 1. Jejunal mucosa, stained by haematoxylin, and having normal finger villi. $\times 32$.

\section{ILLUSTRATIVE CASES}

A 55-year-old previously healthy male patient died suddenly, following a myocardial infarction. Routine histological examination of the jejunal mucosa revealed gross autolysis and valid comment was not possible. A specimen removed at the same time was prepared by the technique outlined above and was examined under a monocular light microscope. It was suitable for photography and showed normal tall finger-like villi (Fig. 1). The intervillous spaces appeared enlarged due to loss of surface mucosa, and this accentuated the slender villous forms.

Similarly, in a 40-year-old patient who died shortly after admission to hospital and who was suspected of having a malabsorption syndrome, a section of jejunum was found by this technique to show a mosaic pattern (Fig. 2), confirming the diagnosis.

\section{DISCUSSION}

Previous attempts to study jejunal mucosal specimens obtained at necropsy have been unsuccessful mainly due to autolytic change (Dawson, 1964) which is particularly rapid in this highly differentiated tissue (Anderson, 1953). This has been overcome in the method described by studying the basic morphology of the villi. During autolysis the superficial epithelial

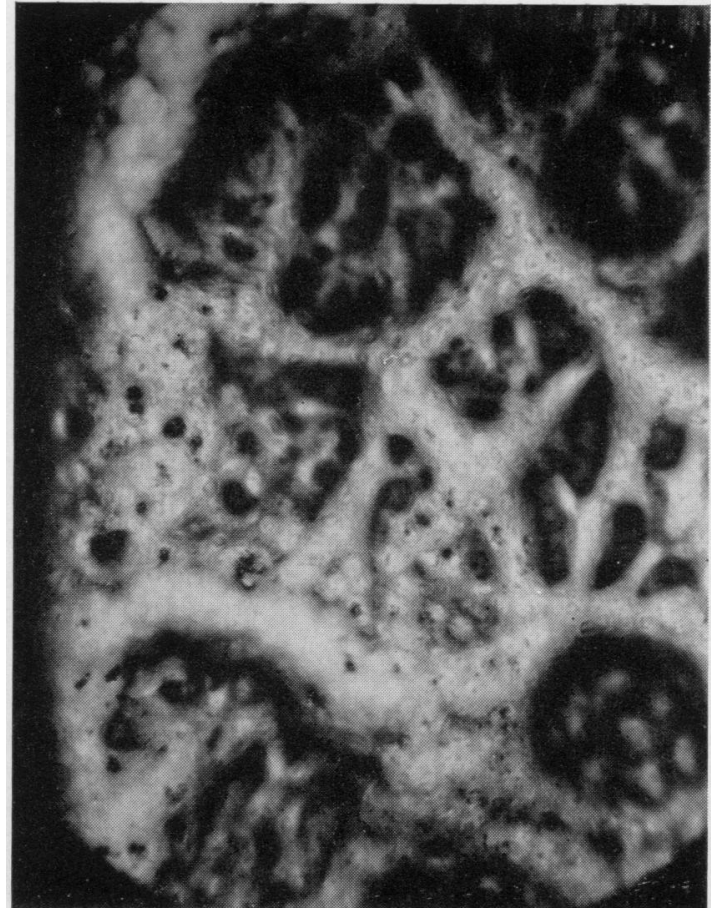

FIG. 2. Mosaic pattern in a grossly autolysed mucosae stained by haematoxylin. $\times 32$.

cells are destroyed but the stroma of connective tissue with or without inflammatory cells is minimally affected. In essence a villous skeleton remains after autolysis and this is readily stainable. Creamer and Leppard (1965) have utilized this same basic principle, employing a different technique and with eosin. We have found that the extent to which eosin is taken up is variable and the resulting preparation does not photograph readily. The use of haematoxylin as a nuclear stain gives a good outline of the villous skeleton and a readily recordable picture.

We should like to acknowledge our indebtedness to Professor S. Alstead and Dr R. R. Wilson, to the late Dr J. C. Dick, Mr J. Mackie, and to Mr P. S. Waldie.

\section{REFERENCES}

Abraham, E. P. (1962). In General Pathology, 3rd ed., edited by H. Florey, p. 412. Lloyd-Luke, London.

Anderson, W. A. D. (1953). In Pathology, 2nd ed., edited by W. A. D. Anderson, p. 90. Kimpton, London.

Creamer, B., and Leppard, P. (1965). Gut, 6, 466

Dawson, A. M. (1964). In Recent Advances in Medicine (Beaumont and Dodds), 14th ed., edited by D. N. Baron, N. Compston, and A. M. Dawson, p. 272. Churchill, London.

Dymock, I. W. (1966). Brit. J. Cancer, 20, 236.

Hindle, W., and Creamer, B. (1965). Brit. med. J., 2, 455.

Salem, S. N., Truelove, S. C., and Richards, W. C. D. (1964). Brit. med. J., 1, 394.

Shuster, S., and Marks, J. (1965). Lancet, 1, 1367. 